\section{International Scientific Journal Theoretical \& Applied Science}

Sardorbek Usmanhudjaevich Abdullayev

The senior scientific researcher The Sociology and social work chair Faculty of Social sciences The Mirzo Ulugbek National University of Uzbekistan asardorbek85@mail.ru

Year: $2015 \quad$ Issue: $11 \quad$ Volume: 31

Published: $30.11 .2015 \quad$ http://T-Science.org

SECTION 30. Philosophy.

\title{
THEORY OF EMPLOYMENT OF THE POPULATION: THE EVOLUTIONARY STAGES OF FORMATION AND SOCIAL POLICY
}

\author{
Abstract: The article presents the theory of evolutionary formation of employment by supporters of classical, \\ Keynesian, monetarist, theory of institutionalism and analysis are given in terms of some representatives of \\ sociological theory. The conceptual framework is considered and main questions of employment development are \\ disclosed by considering today's requirements. \\ Key words: employment, living standards, incomes, salary, social policy, social factor, the classical doctrine, \\ fiscal policy, monetary policy, institutional policy, labour market, interest rate, inflation. \\ Language: English \\ Citation: Abdullayev SU (2015) THEORY OF EMPLOYMENT OF THE POPULATION: THE \\ EVOLUTIONARY STAGES OF FORMATION AND SOCIAL POLICY. ISJ Theoretical \& Applied Science 11 \\ (31): 13-17. \\ Soi: http://s-o-i.org/1.1/TAS-11-31-3 Doi: crossef http://dx.doi.org/10.15863/TAS.2015.11.31.3
}

In some cases the development and prosperity of the state due to the increase of his intellectual level, in many cases with social policy in the country and the employment rate of the population.

Today's major State programs implemented in our country, aimed at the development of social sector in which the employment is steady and the main direction of state policy. In this regard, the President of the Republic of Uzbekistan stressed, "the creation of new jobs, providing employment and increasing incomes are always at the center of our attention" [1].

The employment of the population has a history of evolutionary studies, and thoroughly studied by international scientists, scientists of the CIS countries and our country. Its theoretical basis within frameworks which the research was conducted in the study of the patterns of action of employment in society as social-economic categories was formed and developed within a few years.

The evolutionary stages of formation of the theory of employment were studied by the following scientists of economic and sociological sectors that have divided it into various schools of teachings.

Supporters of the classical theory (A. Smith, D. Ricardo, J. S. Mill, A. Marshall and others) in their studies the absolute employment was described as the backbone of economic development of countries. Its functional character described first A. Smith through the theory of the absolute superiority, then D. Ricardo by the theory of comparative advantage, which is formed on the basis of salary setting through the formation of free supply and demand and free competition. D. Ricardo was based on the theory of dependency of employment from the two rules, i.e., on the relationship between salary and labour supply [2, P. 25-30]. Supporters of this theory in their research were because the problems of absolute and relative employment are the result of equivalent exchange of goods and services. They believe that in matters of employment, the labour supply and the demand for them from employers linked to the level of competition. However, in their research, equivalent equivalent-goods turnover that is competitive value is paramount, the social factor has a secondary importance, and its learning and social characteristics in that era had no special value.

According to the theory of A. Marshall is considered, "despite the fact that at the time of the agreement, the benefit can be distributed equally, in many cases, the advantage goes not to the side of the sellers but the buyer's side", and the trade (exchange of goods) is considered one of the main factors of the implementation of the employment. In this case, they confirm that the constancy of employment, i.e. the ratio of labour supply to demand as a result of the process of trade is a means of achieving of the maximum level of profitability, the acquisition of 
goods in conditions of full employment and price equation for labour, and argue that in case of lack of funds for general expenses, there is a possibility of coordination by means of regulating prices and salary. The total cost savings prevents the reduction of the volume of production, level of employment and lower of real incomes, also warns of forced unemployment because of competition in the labor market and shows that every person who wishes to work with the labor market has the ability to easily find a job with a set salary.

According to the idea of the supporters of the classical school which was based on the theory of "free trade" in employment the main role is played not social factors, but economic factors, which are formed on the basis of supply and demand for goods, i.e. as a result of absolute and relative superiority. Study of the role of various social strata of the population in the society, various levels of employment in development and social change is still an issue.

In the development of employment, the theory of evolutionary changes of G. Spencer actively supported individual liberty of person and freedom of competition in general. The principle of "free competition" of A. Smith has played a significant role in the development point of view of the employment impact on the evolutionary development of society of G. Spencer. He believes that any interference with the natural development of events will lead to a bad promotion at the expense of the good.

In the theoretical development of employment has played a huge role in the formation and improvement of labour sociology. In 20-ies of the XX century on the basis of sociological concepts of F. Taylor, E. Mayo, K. Levin, J. Moreno, F. Herzberg in the USA was formed the labor sociology. The employment requires greater conceptual study than labour sociology and requires a more detailed study of the functional layer from the point of view of labour sociology, is the study on the basis of the content, the nature of work and relationships evolutionary development, also on the basis of relevant intellectualization of busy part of the population to qualitative changes in the society.

The doctrine of the Keynesian school (J. M. Keynes, J. Robinson, R. Harrod, E. Domar and other supporters of this doctrine are called fiscaliste) believed that one of the main challenges of labour market government is to achieve full employment [3]. The theory of the labour market of this school differs from the classical doctrine that in the economy there is no single mechanism that ensures full employment, full employment is not a pattern; on the contrary they believe that it is a random phenomenon and to its regulating the state should pull its levers.
According to this doctrine for employment must impact on the equilibrium of the labor market by changing interest rates, also the elasticity of price changes and salary rates for the labor force stable, the prices for labor are not means of coordination of labour market regulation labour market is a function of the state and that the state has the ability to keep the balance of the labour market by means of increase or decrease total demand, the demand for labor can be resolved not by changing market prices, and by increasing the amount of total demand or production.

J. Keynes in his teaching concluded that the state on a scientific basis must plan the main economic and social indicators (education, health, etc.) costs. This provision proves an indirect role of social factor in proving employment.

He states the harmonizing of employment policy with monetary policy and argues that the social factor play of the special role in the employment generation. He also confirms that by ensuring the state's ability to pay for consumer demand is a way of creating new jobs and ensuring employment of population.

According to F. A. Hayek, unemployment is a direct consequence of the policies for achieving full employment, according to the theories of the Keynesian school [4, P. 93]. He denies the link between employment and investment to create jobs, and argues that even in conditions of high employment demand for huge deposits into production remain unchanged.

From the point of view of supporters of the monetary policy (M. Friedman, R. Lucas, J. Muth, and others) approves employment connection with inflation and indicates that unexpected inflation, which increases the likelihood of damage to workers and increased unemployment that is of great importance. So, the point of view of M. Friedman about the availability of the natural rate of unemployment, its categorical restriction conditions of the labour market and the fact that it cannot be changed by public policy, if the government wants to increase employment through fiscal and credit ways, the measures are short term and the result will lead to higher market prices resulting in a long-term continuation of unemployment is of particular importance [5, P. 70]. This shows the uselessness of the fiscal policy in the long period and the effectiveness of regulation of social spending or productive organization of the monetary units.

The institutional theory (T. Veblen, J. Galbraith, R. Gordon, D. Commons, etc.) believes that the social sector is an important area of the economy, and claims more than growing production and increasing industrialization, competition in prices for services moved to the side of the prices of labour and working conditions [6, P. 56]. Decision of the problem of disproportionality of supply and 
demand in the labour market is possible through the establishment of the social control; in this case, great attention is paid to the social environment. From an administrative point of view, to increase the level of employment in society should influence the labour market through the social institutions.

According to J. Galbraith, the state is interested in the highest level of employment, in that employment increases the income and wealth of the country, and leads to improved social policy [7, P. 406]. In the teaching of supporters of the institutional school put forward the idea that for employment it is necessary to increase the role of social factors, in particular education and increase opportunities to enhance of the professional skills.

Supporters of the Neoinstitutional School (headed by R. Crowson) believe that social institutions play an important role in the formation and administration of employment; there are new institutional structure of a society and claim that it has a restrictive signs in an individual sample space.

Some economists of the CIS countries in the conditions of market economy regulation of labor are equated to employment policy, and the "labour" is equated to "employment". In particular, E. Saruhanov concludes that employment is an introduction to labour relations in the field of appointment are ties in the field of employment. Once people start to work, the effect of the relationship stops, since that time the stage of labour activity, and the employment is not employment related with labor [8, P. 49]. In this case, employment may be regarded as the position associated with the peculiarities of changes in the social strata of the population.

In the opposite views on this point of view the labour market, employment and regulatory processes differ based on the social nature of employment. Supporters of this point of view believe that the reeducation of the labour force and the labour market are an integral part of employment. For example, in the writings of G. G. Rudenko and B. C. Murtozaev put forward the view that the labor market is a market system in the re-implementation of the production abilities of people that the labor market provides an opportunity to the employer the possibility of production of material values by engaging the labour force. The employee, in turn, through the implementation of its labour force gets salary for their work and re-acquires his working ability [9, P. 414] and considers employment as an economic issue, appearing in the system of market relations.

In general, the word "employment" in studies of M. E. Konovalova, O.Y. Balashova is considered as a part of the population occupied by work [10, P. 975-979, стр. 975-979]. In a wide sense this is a complex, differentiated, having institutional strata and structure of social-economic and political task.
S.V. Andreev [11, P. 76] considers employment "a condition of accession to the production process", and sees it in follows:

- production (labour is the means of communication of the employee with the means of production for organizing of production);

- consumption (the work of employee both financially and mentally stimulated);

- division of labor (attach employee to any labour activity).

The area of employment is a comprehensive term, which covers the following: institutions of employment, the labour market, the provision of the population by labour on their own forces, the activity within the framework of household, social activity and targeted programmes aimed at training and providing job. That is, the area of employment is wider than the concept of the labour market, and the settlement of labour market is a part of employment of the population.

The lead scientist of the scientific school in the field of labor resources and employment of our country is K. H. Abdurahmonov [12, P. 542]. He argues, "In the economic theory, employment is interpreted as "a level of involvement of the economically-active population in the economy".

In the researches of H. P. Abulkosimov, A. V. Vakhabov, T. T. Juraeva were studied to clarify the role and tasks of the labour market to enhance labour mobility, and the problem of its actualization [13, P. 215], the impact of socio-economic reforms on employment and social protection; that it is a factor in ensuring the welfare of society [14, P. $320-$ c.320], is consided of the influence factors on the development of the economic theory of employment.

According to D. V. Rasulova [15, P. 271] "retraining the unemployed and proving their by jobs, reducing the period of unemployment can be achieved by maintaining of active employment policy and enhance of independent activity of people in the labour market".

According to A. P. Danilov [16, P. 11-15] formation of the CIS countries have led to the transformation of socio-economic policy based on market mechanisms according to a market economy. Here we can see not only the transformational changes in the economy, but also the need to improve and change of social arrangements for the employment of the society according to the requirements of the time.

On the basis of socio-structural relations and new structural forms, which are the cause of social differentiation and ensuring the transformation of the individual in a social group aimed at values in its radical tendentious changes, formed on the basis of the theory of employment of the institutionalists and their next generation of the neoinstitutionalists that combines evolutionary changes in the development 


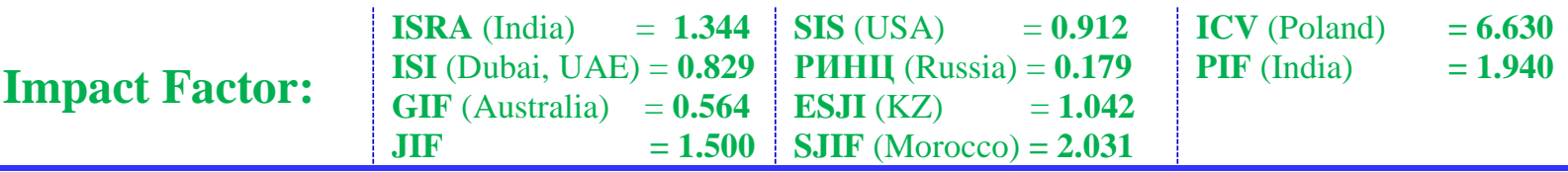

of society, there was a pattern of forms of employment.

The employment's problems due to its evolutionary development of various transformational change, on the basis of their intellectual labor resource as a socio-economic category, requires the development of education, which contributes to its improvement and development of young people aspiring to acquire the social status of the intellectual and professional level as a new labor force.

P. Sztompka [17, P. 26-31, 86-89] offering to see the society not as a statistical and categorical "quasi" object, but as an ongoing process consisting of infinite streams of events, which covers the sequence of social processes and, in turn, employment is a social process in which the employment of the youth considers its social status. On this basis, if we assume that the employment of the youth model of social behavior, i.e. social status, then the process should be divided into two factors the vertical and the horizontal factor. To improve of its vertical status the young people to strive to acquire a profession and a high professional level. The horizontal status is considered to fill of vacancies by youth, and finding your place in the society.

In the Republic of Uzbekistan the data of the vertical and the horizontal vectors of employment are seen as a factor that increases the social status of youth in the framework of social institutions and the system of higher and secondary special education. Social stratification within the paradigm of globalization, the awareness of tendentious changes based on the requirements of the theory of structuralfunctional and non-institutional structures and empirical materials is an important task facing our society.

Conclusion and suggestions. The tendency of formation of social strata of the regulation of the education system as a social mechanism for the employment and the activity of social institutions that provide employment in the labour market requires the creation of a new concept of employment.

Due to the presence of the difference between supply and demand on the labour market, in particular based on the needs of the labour market, it is necessary to improve and reform the system of training in accordance with the program of training of modern highly intellectual personnel.

For the providing of reform of the education system, it is advisable to convert the system of administrative governance in the corporate governance system and requires identifying and liberalization of the distribution of roles in professional educational space within the vertical administrative management.

Based on the requirements of the labour market, increase the compliance of professions and specialties of the higher education graduates with market requirements.

Based on the requirements of the policy of industrialization in the country, it is need to create mobile centers for the retraining of the unemployed and the older generation who have lost their jobs because of structural reforms.

\section{References:}

1. Karimov IA (2014) Doklad na zasedanii Kabineta Ministrov posvjashhennyj itogam social'no-jekonomicheskogo razvitija strany $\mathrm{v}$ 2013 goda takzhe ustojichivym napravlenijam jekonomicheskoj programmy 2014 goda //Narodnoe slovo. 19 jan 2014.

2. Rikardo D (1961) Sochinenija. - Moscow:1961.

3. Dzhon Mejnard Kejns (2002) Obshhaja teorija zanjatosti, procenta i deneg. (The General Theory of Employment, Interest and Money). Serija: Klassiki jekonomicheskoj nauki - XX vek Izdatel'stvo: Gelios ARV, 2002. Tverdyj pereplet, $352 \mathrm{p}$.

4. Hajek FA (1990) Obshhestvo svobodnyh / Per. s angl. - Moscow, 1990.

5. Friedman M (1973) Money and Economic Development/ M.Friedman// 1973. №4.
6. Veblen T (1984) Teorija prazdnogo klassa. Moscow: Progress, 1984.

7. Gjelbrajt D (1979) Jekonomicheskaja teorija i celi obshhestva. -Moscow:Nauka. 1979.

8. Saruhanov J (1995) Rynok truda i rynok zanjatosti: protivorechija, opredelenija i traktovki //- M.: Zh.Chelovek i trud. 1995. №2.

9. Rudenko GG, Murtozaev BC (2004) Formirovanie rynkov truda. - Moscow: «Jekzamen», 2004.

10. Konovalova ME, Balashova OJ (2012) Teoreticheskie podhody $\mathrm{v}$ issledovanii kategorii «zanjatost' naselenija»// Jekonomicheskie nauki, № 11 za 2012 god (chast' 4).

11. Andreev SV (1997) Kadrovyj potencial i problemy zanjatosti v uslovijah perehoda Rossii 
\begin{tabular}{l|lr|ll|ll} 
& ISRA (India) & $=\mathbf{1 . 3 4 4}$ & SIS (USA) & $=\mathbf{0 . 9 1 2}$ & ICV (Poland) & $=\mathbf{6 . 6 3 0}$ \\
Impact Factor: & ISI (Dubai, UAE) $=\mathbf{0 . 8 2 9}$ & PUHIL (Russia) $=\mathbf{0 . 1 7 9}$ & PIF (India) & $=\mathbf{1 . 9 4 0}$ \\
& GIF (Australia) & $\mathbf{0 . 5 6 4}$ & ESJI (KZ) & $=\mathbf{1 . 0 4 2}$ & & \\
\hline JIF & $=\mathbf{1 . 5 0 0}$ & SJIF (Morocco) $=\mathbf{2 . 0 3 1}$ & &
\end{tabular}

k rynochnym otnoshenijam. -M.: Institut sociologii RAN. 1997.

12. Abdurahmonov KH (2012) Chelovecheskij progress. - T.: Jekonomika, 2012.

13.-Abulkosimov H, et al. (2009) Puti usovershenstvovanija regulirovanija podgotovku kadrov dlja nacional'nogo rynka. T.: "Nauka i tehnologija", 2009.

14. Vahabov AV (2003) Social'nye fondy v sisteme riynochnyh otnoshenij. - T.: Shark, 2003.
15. Rasulova DV (2010) Teoreticheskie osnovy razvitija migracii rabochej sily. // Monografija. Tashkent, Izdatel'stvo "Molija", 2010.

16. Danilov AN (1997) Perehodnoe obshhestvo: problemy sistemnoj transformacii. Minsk: Universitetskoe, 1997.

17. Shtompka P (1996) Sociologija social'nyh izmenenij/Per. s angl. pod red. V.A. Jadova. Moscow: Aspekt Press, 1996. 